\title{
短報 自己免疫性溶血性貧血を伴い多彩な症状を呈した
}

\section{systemic lupus erythematosus (SLE)}

\author{
にパルス療法が有効であった 1 例
}

福島県立医科大学第一内科

後田真一寺嶋力ヤ, 今野正巳 吉田幹男 小松正文
佐藤 正 松田 信 内田立身 刏米重夫

概要 22才女性, 重篤な貫血, 蛋白尿で発症し, 胸水, 腹水, 心膜液貯留をきたした続発性自 己免疫性溶血性貫血（secondary AIHA），ループス腎资合併systemic lupus erythematosus にステロイドパルス療法を試みた。結果は、ループス腎炎のみならず，従来の経ロステロイド 薬でも効果不十分であった secondary AIHAに対しても良好な結果を得ることができた。 AIHAに対するパルス療法の報告は少なく本例は責重な症例と思われた.

[日内会誌 $77: 736 〜 737,1988$ ]

緒言：ステロイドパルス療法は，ループス腎 炎のみならず，再生不良性筫血などの血液疾患に 西拡大応用されるよらになってきた、今回我々は， 多彩な症状を呈した systemic lupus erythematosus (SLE) に続発したAutoimmune hemolytic anemia (AIHA) にステロイドパルス 療法を行ないSLEのみならずAIHAにも有効で あった症例を経験したので報告する。

症例：22才，女性。主訴: 発熱。現病歴： 昭和 59 年 2 月，某病院にて蛋白尿を指摘されその 後入退院を繰り返していたが，昭和60年 2 月，発 熱，極度の賓血拈よ゙蛋白尿が出現したため，当 科入入院した，入院時現症：身長 $159 \mathrm{~cm}$, 体重 $48.5 \mathrm{~kg}$, 体温 $38^{\circ} \mathrm{C}$, 血王 $100 / 60 \mathrm{mmHg}$, 脈拍 $84 /$ 分 整，頭部に脱毛，紅斑，浮腫なし，眼倹結膜に賞 血あり球結膜に黄宣なし，胸部でラ音なく，心尖 部に収樎期心雑音（Levine II/VI）を聴取，腹部 で肢脾を触れず，四肢に浮腫なく神経学的に異常 なし，入院時検查成績：血沈 1 時間値 $146 \mathrm{~mm}$ と
亢進，末梢血で赤血球 84 万 $/ \mathrm{ul}, \mathrm{Hb} 4.1 \mathrm{~g} / \mathrm{dl}$ と低下， 網赤血球 $304 \%$ 上増加，骨髄で有核細胞数26.7万/ ul, M/E比0.54 と赤芽球系の過形成を認めた。生 化学娭査でLDH 803WrU上高值でI型優位, 総ビ リルビン $2.0 \mathrm{mg} / \mathrm{dl}$ (間接ビリルビン $1.2 \mathrm{mg} / \mathrm{dl}$ ) と 上昇，ハプトグロビン $10 \mathrm{mg} / \mathrm{dl}$ と低值，束た $10 \mathrm{~g} /$ 日 程度の蛋白尿を認め血清総蛋白 $5.0 \mathrm{~g} / \mathrm{dl}$ と減少. 血 清学検查では，クームス試験の直接法，間接法と も陽性，赤血球自己抗体検索ではIgG-補体型，ま た $\mathrm{C}_{3}, \mathrm{C}_{4}, \mathrm{CH}_{50}$ が低下. LE試験は弱陽性，抗核抗 体は320倍陽性でspeckled pattern，抗DNA，抗 ENA抗体は陰性，さらに腹部X線写真で腹水の貯 留を認めた。入院後経過（图 1)：入院の翌日， 顔面に蝶形紅斑が出現，また高度な蛋白尿，網赤 血球增加を伴亏溶血性貧血そして抗核抗体陽性の 4 項目よりSLEと診断した。 たた貧血に関して は，亦血球自己抗体模索の結果IgG.補体型の温式 型AIHAと診断され，prednisolone $60 \mathrm{mg} /$ 日で治 療を開始した。3月に入り $25 \mathrm{~g} /$ 日以上の蛋白尿と

[昭和60年9月28日 第117回東北地方会推薦]

Systemic lupus erythematosus associated with autoimmune hemolytic anemia and diversified symptoms responsive to Methylprednisolone Pulse Therapy: a case report.

Shinichi Ushiroda, Kayano Terashima, Masami Konno, Mikio Yoshrda, Masafumi Komatsu, Tadashi Sato, Shin Matsuda, Tatsumi Uchida and Shigeo Kariyone, The First Department of Internal Medicine, Fukushima Medical College, Fukushima 


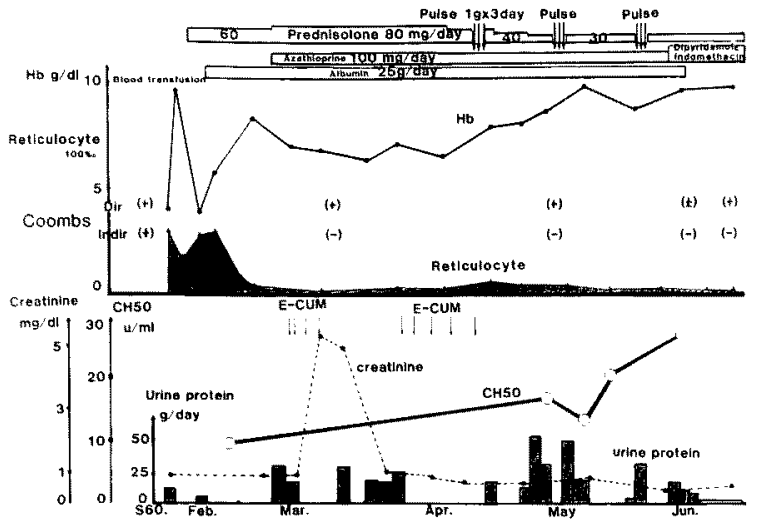

図 1 . 入院後経過

全身の著明な浮腫が出現し, prednisolone $80 \mathrm{mg}$ / 日に增量し同時にazathioprine $100 \mathrm{mg}$ /日を迫加 した。 また浮腫に対し除水目的で第 1 回目の透析 ECUM (extra corporeal ultra filtration method) を行なった。その結果全身の浮腫は改善を示した が, 4 月に入り再び浮腫が出現.この時の胸部X線 像でCTR $60 \%$ と抁大し肺うっ血と胸水の貯留を 認めた。さらに心ェコーで中等量の心膜液の貯留 むみられた。このため第2 回目の透析を行ない， 胸水抢よび心膜液の消失をみ，CTR $45 \%$ 之縮小 した。しかし依然として25g/日以上の蛋白录が持 続しているため、このループス腎炎に対してパル ス療法 (methylprednisolone $1 \mathrm{~g} /$ 日を3日連続静 注)䒚 3 クール施行し, 後㞠法として prednisolone $30 \mathrm{mg} /$ 日の経口投与掞よびdipyridamole $225 \mathrm{mg} /$ 日, indomethacin $75 \mathrm{mg}$ /日の併用を行った。 その 結果尿中蛋白排泄量は $3 \mathrm{~g} /$ 日以下に改善し血清補 体価著明に上昇を示した。京た抗核抗体，LE試 橰もそれぞれ陰性化した。さらにAIHAに関して も黄疸の消失, パルス療法前のへモグロビン7.1 $\mathrm{g} / \mathrm{dl}$ が $9.8 \mathrm{~g} / \mathrm{dl}$ へと増加しタームス試験の直接法 が弱陽性化，間接法が陰性化を示し軽快退院する までになった。

考案： 本症例ではループス腎炎にAIHAの合 併をみ、ステロイドパルス療法が有効であったが， ループス腎炎に対するパルス療法の有効性は，厚 生省特定疾患膠原病治療調查研究班の成績 ${ }^{1} な と ゙$
によって栚来のステロイド経口大量投与法よりも 有用であることが明らかにさ机ている。しかし AIHAに対するステロイドパルス療法の報告は少 なく1983年 Takaue ら²の小児のSLE続発性 AIHAの急性期にmethylprednisoloneによるバル 又療法を施行し短期間に汪とんど副作用なく血液 学的筧解に導入した 1 例が報告されている。この 報告では 2 クールのパルス療法啳血液学的寛解に 入ったとしているが，括およそ治療開始後20日 ～30日の間上推定される. 本症例でも従来の経口 ステロイド薬によってある程度の $\mathrm{Hb}$ 值の回復を みたが，血液学的には部分寛解 $(\mathrm{Hb} \geqq 9 \mathrm{~g} / \mathrm{dl}$, 網赤 血球数 $\leqq 60 \%$ ）以下の状態で経過していた。 しか しパルス療法を始めてからHb值がさらに増加傾 向を示し 2 クール終了後の22日目で部分寛解の状 態に達している.SLE続発性AIHAは特発性 AIHAに比べて prednisolone治療量が $1.33 \pm 0.40$ $\mathrm{mg} / \mathrm{kg}$ と後者の $1.18 \pm 0.45 \mathrm{mg} / \mathrm{kg}$ よりやや多い 傾向にあるが治療の反応性は概して良好で血液学 的寛解に達するまでの期間む29土25日で後者の $36 \pm 33$ 日より短い例が多い3)。これがさらにパル ス療法によって彷来の経口ステロイド薬による寛 解導入期間より短縮させることができるかどう か，また従来の治療によっても寛解に入ることが できなかった症例に対しても有効であるかどらか はAIHAに対してのパルス療法実施例数が少ない ことも西って今後症例者増やして娭討すべきもの と考党られる。

\section{文献}

1）本間光夫，他：ループス腎炎に対するパス㞠法 の対照試験。厚生省特定疾患膠原病治㞠調查研究 班，昭和 56 年度業績，1982, p277。

2) Takaue $Y$, et al: Effective "pulse" methylprednisolone therapy in a case of autoimmune hemolytic anemia associated with systemic lupus erythematosus. Acta Haematol Jpn 46 : $989,1983$.

3）前川正，他：自己免疫性搈血性責血のプロスペ クティブ研究集計成綪一昭和 59 年 -60 年度追加解 析一, 厚生省特定疾患特発性造血障害調查研究班, 昭和60年度研究報告畫, $1986, \mathrm{p} 343$. 